\title{
Website quality: An analysis of scientific production
}

\author{
Alejandro Morales-Vargas; Rafael Pedraza-Jiménez; Lluís Codina
}

Nota: Este artículo se puede leer en español en:

http://www.elprofesionaldelainformacion.com/contenidos/2020/sep/morales-pedraza-codina_es.pdf

How to cite this article:

Morales-Vargas, Alejandro; Pedraza-Jiménez, Rafael; Codina, Lluís (2020). "Website quality: An analysis of scientific production". Profesional de la información, v. 29, n. 5, e290508.

https://doi.org/10.3145/epi.2020.sep.08

Manuscript received on $13^{\text {th }}$ December 2020 Accepted on $04^{\text {th }}$ June 2020
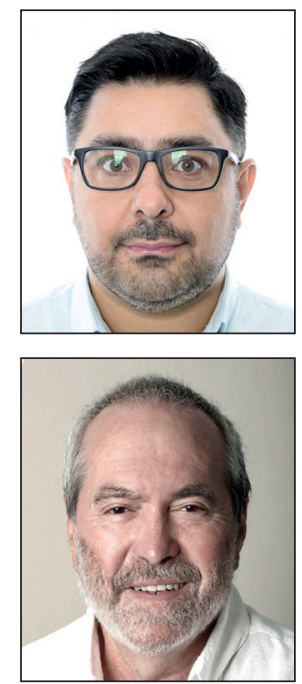

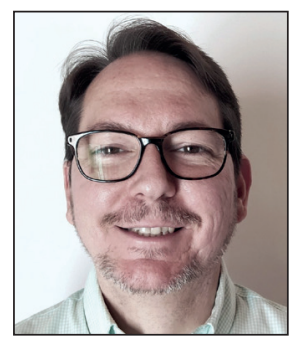

Rafael Pedraza-Jiménez https://orcid.org/0000-0002-6918-6910

Universitat Pompeu Fabra Departament de Comunicació Roc Boronat, 138. 08018 Barcelona, Spain rafael.pedraza@upf.edu

\section{Abstract}

A range of different methods and tools have been proposed by both academics and professionals in recent years for evaluating the quality of websites. Some are of general application and can be used to assess any type of website, while others have been adapted to the specialized characteristics of the websites employed in a given sector. This paper undertakes an analysis of existing scientific production in this field, with the aim of identifying its most relevant publications, its principal authors and the specific sectors served by the sites under evaluation. By triangulating review methods, 716 texts, published between 2000 and 2018, were identified in Scopus, Web of Science and other databases and examined. In addition to basic bibliographic information, the number of citations received by each text was recorded using Google Scholar. The area of knowledge in which each author works was also categorized based on his or her specific affiliations. The results point to a growing interest in website quality in a scientific community that has a presence in more than 70 countries. Its authors are drawn from various disciplines, although the highest number of publications is recorded in computer science, business and medical informatics. The most frequently cited texts are in fact seminal books in the associated disciplines of usability, information architecture and user experience. However, as of 2007, the number of texts describing evaluation tools for the websites of specific sectors - most notably, education (33\%), health (27\%) and commerce (21\%) - increased their share. In conclusion, it is evident that website quality is a field of study undergoing constant growth and increasing specialization and one that offers ample opportunities for research.

\section{Keywords}

Website quality; Websites; Scientific production analysis; Systematic literature review; Review article; Heuristics; Expert analysis; Usability; Contents; User experience; Standards; Guidelines.

\section{Funding}

This work is part of the Project "Interactive storytelling and digital visibility in interactive documentary and structured journalism". RTI2018-095714-B-C21 (Micinn/Feder) Ministry of Science, Innovation and Universities of Spain. It was also supported by National Research and Development Agency (ANID) of Chile, via its Scholarships for Doctorates Abroad Program. 


\section{Introduction}

Thirty years after its invention, the Internet is today the world's most widely used communication channel. Estimates place the number of active sites at more than one hundred million and calculations indicate that more than half the planet's population are users (Internet Live Stats, 2020). This emphasises just how important it is that websites comply with basic principles of quality in a broad diversity of characteristics that include their content, organization, interface visual design, and user-friendliness. Indeed, this concern has been maintained independently of the continuous technological advances that have been made, including the development of the social web and the mobile web.

Faced with what is a vast, competitive scenario, those responsible for websites are in need of guidelines that can help them optimize their sites. Nowhere is this truer than for large-scale, content-intensive sites (Pérez-Montoro; Codina, 2017), which require specific tools and indicators for evaluating their quality. In light of demands to this end from both the academic world and the professions, numerous proposals have been made, published in journal articles and books or laid down as standards and guidelines.

This study seeks to characterize this literature on website evaluation, with its different methods and tools, and to identify both its leading authors and the sectors that these studies specifically address. And it does so on the understanding that, over the years, website quality has developed into a specific field of study, one that is increasingly interdisciplinary and specialized in nature.

\section{Defining website quality}

The concept of quality is defined by ISO 9000 as

"the degree to which a set of inherent characteristics of an object fulfils requirements" (ISO, 2015),

and, in ISO 9241-151, while we find guidance for World Wide Web user interfaces, no specific definition is provided (ISO, 2008).

Aladwani and Palvia warned, almost two decades ago, that

"web quality is a vastly undefined concept" (Aladwani; Palvia, 2002, p. 468).

Semerádová and Weinlich (2020) continue to stress that, despite the numerous studies that have been conducted on the matter, a uniform definition of website quality has yet to be formulated.

Olsina, Covella and Rossi point out that while the quality of a website is easy to recognize, it is difficult to define and evaluate:

"The meaning of quality is not simple and atomic, but a multidimensional and abstract concept" (Olsina; Covella; Rossi, 2006, p. 109).

The authors go on to say that website quality evaluation is based on the quantification of entities and attributes, where an attribute is a measurable property of an entity. As such, quality is an abstract relationship between attributes of entities and measurement goals.

Elsewhere, Anusha (2014) claims that website quality can be measured from two perspectives:

- that of programmers, and

- that of end users.

The former focus their attention on the degree of maintainability, security and functionality, while the latter pay greater attention to usability, efficiency and creditability.

Similarly, Rocha (2012) breaks down his definition of website quality into three dimensions:

- content quality,

- service quality, and

- technical quality,

while Hasan and Abuelrub (2011) also think in terms of dimensions, and identify four key criteria underpinning the concept of website quality:

- content

- design

- organization

- user-friendliness.

Drawing on these definitions, and given that no unified formal definition has yet to be formulated, we propose that website quality can be considered the ability of a website to meet the expectations of its users and owners, as determined by a set of measurable attributes. 
Note, we do not speak about meeting needs, but rather expectations, on the understanding that, while a website may provide a given service, it might also cause frustration among its users and fail to meet the objectives of the site managers. Nor do we limit this definition to those who solely browse the site, but we also include other interested parties, given that a site's owners and managers also use it and have their expectations about what it can offer.

Moreover, we opt to stress the term "attributes", as opposed to "dimensions" or "criteria", since although their identification and selection may be made based on the interests of the researchers undertaking a particular evaluation, the concept of attribute implies an intrinsic condition or quality of the site.

Here, for the purposes of this study, we will however refer to website quality in its broadest sense, that is, as the discipline that concerns itself with evaluating the quality of the strategic, functional and technical features of websites as well as with their specific content.

\section{Theoretical framework}

Concern for website quality emerged virtually in tandem with their creation. From the outset, interface design and human-computer interaction professionals -including, Nielsen (2000), Shneiderman (2000) and Norman (2002)- warned of the need for websites to include certain attributes that would guarantee optimal user experience.

And it was in this way that the evaluation of website quality was born, a process described by Dragunalescu as both complex and critical, since it involved such concepts as quality, objectivity and accuracy, and in which

"evaluative judgments are frequently followed by important deliberative and decision-making processes" (Drăgulănescu, 2002, p. 247).

A range of different approaches, trends and methods have been developed for evaluating website quality; but, in general, they can be classified in two main groups: user studies, and expert analysis (Codina; Pedraza-Jiménez, 2016).

Among the former, studies of website usability, that is, attempts at measuring interface user-friendliness, stand out (Nielsen, 2000; Norman, 2002). More specifically, usability can be defined as the ability of website applications to support the tasks of providing information and services effectively and efficiently while guaranteeing satisfaction Matera; Rizzo; Carughi, 2006).

Initially, the measurement of web usability remained solely descriptive. But over the years, it has become more closely linked to the experimental paradigm, incorporating user testing (Rubin; Chisnell, 2008) and quantitative methodologies based on statistics (Sauro, 2010; Sauro; Lewis, 2012) and the collection of usability metrics (Tullis; Albert, 2013).

Studies of this type have also adopted the qualitative methods of the social sciences, most notably surveys, observations and interviews related to interface design (Tidwell, 2006; Garrett, 2011). In this way, the concept of "usability" has evolved into what we now refer to as "user experience" (UX), understood as the perception and responses registered by those that use a product, system or service.

The second group of website evaluations are characterized by expert analysis formulated and applied by information professionals. Their earliest formats took the form of heuristics (Nielsen, 2005), principles (Tognazzini, 2014), recommendations (Krug, 2014), rules (Shneiderman, 2016), guidelines (Leavitt; Shneiderman, 2006), and standards (Bevan, 2005).

However, it was the heuristic evaluations (Hassan-Montero; Martín-Fernández, 2003) that provided expert analysis with a tool that facilitated their reproducibility. Formulated as checkpoints or as a series of questions, they are relatively easy to apply and allow a comparison of results from different websites to be made (Jiménez et al., 2012).

The more complex versions of these evaluations can incorporate different dimensions (including, parameters and indicators) and allow scores to be awarded. They are particularly suited to case studies and comparative analyses. Some of these tools are for general use, that is, for evaluating sites from any sector (Codina, 2008), while others are specific to a given sector, such as e-commerce or tourism (Pedraza-Jiménez; Codina; Guallar, 2016).

These systems of analysis also present different levels of automation (Hasan; Abuelrub, 2011). Thus, they may be applied manually by experts (Allen et al., 2006); be semi-automatic, applied with software support (Pribeanu, 2009; Afonso; Reis-Lima; Pérez-Cota, 2012) or with a mathematical model that makes multi-criteria decisions (Rekik; Kallel; Alimi, 2015); or operate in a completely automated fashion, based on artificial intelligence and machine learning (Jayanthi; Krishnakumari, 2016). 
Mention should also be made of the existence of a line of quality evaluations focused on the effectiveness of the website in terms of its strategic conception. They are based on the premise that, while a site might be well built from a technical perspective, it may not respond to the purpose for which it was designed and so fail in its task (Sanabre-Vives; Pedraza-Jiménez; Codina, 2018).
Expert analysis are applied by information professionals and are expressed as heuristics, principles, recommendations, rules, guidelines and standards

Thus, we have witnessed the development of integrated models, such as the three-dimensional cube proposed by Ramler et al. (2002), later systematized by Calero, Ruiz and Piattini (2005) under the name Web Quality Model. This integrates and evaluates three dimensions related to web attributes, quality characteristics, and lifecycle processes.

Other strategy-oriented models include

- WebQual (Barnes; Vidgen, 2001);

- WebQual'TM (Loiacono; Watson; Goodhue, 2002);

- Web Assessment Index (Hernández; Jiménez; Martín, 2009);

- Web Performance Index (Kaur; Gupta, 2014);

- Pequal (Wątróbski et al., 2016);

- An analytical system known as Double Entry with Patterns. (Sanabre-Vives; Pedraza-Jiménez; Vinyals-Mirabent, 2020)

Finally, although they constitute disciplines in their own right, to this line of strategic models we can add

- webmetrics (Thelwall, 2002; Orduña-Malea; Aguillo, 2014), which measures a website's impact;

- search engine positioning or optimization (SEO) (Lopezosa, 2019);

- web analytics, which among other aspects evaluates performance indicators (Cutroni, 2010; Clifton, 2012) such as KPIs (key performance indicators) (Kaushik, 2010), the conversion rate or the return on investment (ROI) (Tonkin; Whitmore; Cutroni, 2010).

\section{Previous bibliographic reviews}

A number of previous studies have analysed scientific production in the field of the quality evaluation of websites. Table 1 provides details of the 17 review articles examined in this study. Most follow the guidelines for systematic reviews in software engineering as proposed by Kitchenham and Charters (2007) or employ the method outlined by Webster and Watson (2002).

Among the main contributions made by these studies, special mention should be made of their applied classifications and the criteria employed for grouping the articles under review. For example, Rekik et al. (2018) classify the evaluation tools according to the type of site and the category or sector it is used in (e.g. health, education, etc.). In contrast, Chiou, Lin and Perng (2010) classify the studies according to their methodology.

Elsewhere, Quiñones and Rusu (2017) base their systematic review on usability heuristics and on the way in which these were created. Similarly, Jiménez-Iglesias, Pérez-Montoro and Sánchez-Gómez (2017) propose a five-way division of their heuristic indicators into institutional, governmental, expert, online and scientific categories.

Mariage, Vanderdonckt and Pribeanu (2006) focus their study on web usability guidelines, which they categorise as principles, guidelines, standards, style guides, recommendations, ergonomic algorithms and design rules.

Bevan (2005) does the same with guidelines and standards, comparing the 125 aspects covered by the ISO standards related to web quality, with the 187 usability guidelines of the US Department of Health and Human Services (HHS) and the 121 guidelines for academic websites in the UK. Fogli and Guida (2015), in turn, classify the instruments between those based on international standards and those that constitute original models.

In the field of applied usability, Fernández, Insfran and Abrahão (2011) map the main evaluation methods for the web, detecting gaps and opportunities. A similar study was undertaken by Ugras et al. (2016), in which they characterized research trends and areas of application. González-Sánchez, Montero-Simarro and Gutiérrez-Vela (2012) studied the evolution of the concept of 'usability' as an indicator of software quality in more than 1,600 articles. They conclude that this term begins to disappear after 2007 to be replaced by 'user experience' (UX).

UX is the focus of Maia and Furtado's (2016) review, in which the authors note that researchers do not apply psycho-physiological measures, preferring qualitative approaches and manual evaluations.

Finally, Ivory and Hearst (2001) presented a highly cited study on automated user interface evaluation tools, grouped into the following categories: testing, inspection, inquiry, analytical modelling, and simulation. 
Table 1. Previous literature reviews of website quality studies

\begin{tabular}{|c|c|c|c|c|}
\hline $\begin{array}{l}\text { Author(s) and year of } \\
\text { publication }\end{array}$ & Title of study & Period analysed & $\begin{array}{l}\text { Sample } \\
\text { size }\end{array}$ & Method \\
\hline Díaz et al. (2019) & $\begin{array}{l}\text { A systematic literature review about quantitative metrics to } \\
\text { evaluate the usability of e-commerce web sites }\end{array}$ & $\begin{array}{l}2014-2018 \\
\quad(5 \text { years })\end{array}$ & 13 & $\begin{array}{l}\text { Systematic } \\
\text { review }\end{array}$ \\
\hline Rekik et al. (2018) & $\begin{array}{l}\text { Assessing web sites quality: A systematic literature review by } \\
\text { text and association rules mining }\end{array}$ & $\begin{array}{l}2009-2015 \\
(6 \text { years })\end{array}$ & 532 & $\begin{array}{l}\text { Systematic } \\
\text { review }\end{array}$ \\
\hline $\begin{array}{l}\text { Jiménez-Iglesias; Pérez- } \\
\text { Montoro; Sánchez-Gómez } \\
\text { (2017) }\end{array}$ & $\begin{array}{l}\text { Diseño de información digital: revisión y clasificación de indicado- } \\
\text { res heurísticos para contenidos web [Digital information design: } \\
\text { review and classification of heuristic indicators for web content] }\end{array}$ & $\begin{array}{l}1988-2017 \\
(29 \text { years })\end{array}$ & 44 & $\begin{array}{l}\text { Systematic } \\
\text { mapping }\end{array}$ \\
\hline Quiñones; Rusu (2017) & $\begin{array}{l}\text { How to develop usability heuristics: A systematic literature } \\
\text { review }\end{array}$ & $\begin{array}{l}2006-2016 \\
(10 \text { years })\end{array}$ & 76 & $\begin{array}{l}\text { Systematic } \\
\text { review }\end{array}$ \\
\hline Maia; Furtado (2016) & A systematic review about user experience evaluation & $\begin{array}{l}2010-2015 \\
(5 \text { years })\end{array}$ & 25 & $\begin{array}{l}\text { Systematic } \\
\text { review }\end{array}$ \\
\hline Ugras et al. (2016) & Research trends in web site usability: A systematic review & $\begin{array}{l}2005-2014 \\
\quad(9 \text { years })\end{array}$ & 199 & $\begin{array}{l}\text { Systematic } \\
\text { review }\end{array}$ \\
\hline Abdallah; Jaleel (2015) & $\begin{array}{l}\text { Website appeal: Development of an assessment tool and } \\
\text { evaluation framework of e-marketing }\end{array}$ & $\begin{array}{l}2000-2015 \\
(15 \text { years })\end{array}$ & 133 & $\begin{array}{l}\text { Systematic } \\
\text { review }\end{array}$ \\
\hline $\begin{array}{l}\text { Bevan; Carter; Harker } \\
(2015)\end{array}$ & $\begin{array}{l}\text { ISO 9241-11 Revised: What have we learnt about usability since } \\
\text { 1998? }\end{array}$ & $\begin{array}{l}1998-2015 \\
(17 \text { years })\end{array}$ & 22 & State of the art \\
\hline Fogli; Guida (2015) & $\begin{array}{l}\text { A practical approach to the assessment of quality in use of } \\
\text { corporate web sites }\end{array}$ & $\begin{array}{l}2002-2012 \\
(10 \text { years })\end{array}$ & 23 & State of the art \\
\hline Tapia-León (2015) & $\begin{array}{l}\text { Factores de calidad en sitios web de destinos turísticos: estado } \\
\text { de la cuestión [Quality factors in tourist destination websites: } \\
\text { state of the art] }\end{array}$ & $\begin{array}{l}2005-2015 \\
(10 \text { years })\end{array}$ & +30 & State of the art \\
\hline $\begin{array}{l}\text { González-Sánchez; } \\
\text { Montero-Simarro; } \\
\text { Gutiérrez-Vela (2012) }\end{array}$ & $\begin{array}{l}\text { Evolución del concepto de usabilidad como indicador de } \\
\text { calidad del software [Evolution of the concept of usability as } \\
\text { an indicator of software quality] }\end{array}$ & $\begin{array}{l}1991-2011 \\
(20 \text { years })\end{array}$ & $+1,600$ & $\begin{array}{l}\text { Analysis of } \\
\text { scientific } \\
\text { production, } \\
\text { bibliometric } \\
\text { analysis }\end{array}$ \\
\hline $\begin{array}{l}\text { Fernández; Insfran; } \\
\text { Abrahão (2011) }\end{array}$ & $\begin{array}{l}\text { Usability evaluation methods for the web: A systematic map- } \\
\text { ping study }\end{array}$ & $\begin{array}{l}1996-2009 \\
(14 \text { years })\end{array}$ & 206 & $\begin{array}{l}\text { Systematic } \\
\text { mapping }\end{array}$ \\
\hline Hasan; Abuelrub (2011) & Assessing the quality of web sites & $\begin{array}{l}1999-2009 \\
(10 \text { years })\end{array}$ & 76 & $\begin{array}{l}\text { Systematic } \\
\text { review }\end{array}$ \\
\hline Chiou; Lin; Perng (2010) & $\begin{array}{l}\text { A strategic framework for website evaluation based on a } \\
\text { review of the literature from 1995-2006 }\end{array}$ & $\begin{array}{l}1995-2006 \\
(11 \text { years })\end{array}$ & 83 & $\begin{array}{l}\text { Systematic } \\
\text { review }\end{array}$ \\
\hline $\begin{array}{l}\text { Mariage; Vanderdonckt; } \\
\text { Pribeanu (2006) }\end{array}$ & State of the art of web usability guidelines & $\begin{array}{l}1986-2006 \\
(20 \text { years })\end{array}$ & 69 & State of the art \\
\hline Bevan (2005) & Guidelines and standards for web usability & $\begin{array}{l}2001-2005 \\
(4 \text { years })\end{array}$ & 433 & Comparison \\
\hline Ivory; Hearst (2001) & $\begin{array}{l}\text { The state of the art in automating usability evaluation of user } \\
\text { interfaces }\end{array}$ & $\begin{array}{l}1985-2001 \\
(16 \text { years })\end{array}$ & 132 & State of the art \\
\hline
\end{tabular}

\section{Objectives}

The primary objective of the present study is to analyse and characterise scientific production in the field of website quality evaluation. To do so, we have examined studies published between 2000 and 2018. The achievement of this objective, however, is subject to the fulfilment of the following specific objectives (SO):

SO 1: Determination of the most relevant academic and professional publications in this field.

SO 2: Identification of the principal authors, the countries in which they work, and the disciplines to which they belong.

SO 3: Identification of the type of website their studies seek to evaluate.

\section{Methodology}

This study constitutes an analysis of scientific production and employs a triangulation of the following methods (Grant; Booth, 2009).

- First, we record elements from bibliometric studies, which enables us to identify the leading authors in the field, the journals that are consulted most frequently, and the thematic areas in which they primarily focus, thus providing an overview of production in this specific discipline (Abadal; Guallar, 2018).

- Second, to constitute the document bank and undertake an in-depth analysis of it, we undertook a systematic review (Booth; Sutton; Papaioannou, 2016) employing for this purpose academic databases, in an effort to avoid any bias and to guarantee maximum transparency and traceability. 
- Finally, to make the analysis as exhaustive as possible, we also undertook a systematic mapping (Gough; Oliver; Thomas, 2017), thus identifying a very broad set of relevant studies.

The Prisma model was used to document the selection process of our evidence-based analysis (Moher et al., 2009) and, by way of a general protocol, we worked within the Salsa framework (Grant; Booth, 2009; Codina, 2018), which includes the following stages: search, appraisal, analysis, and synthesis. Below, we provide details of each step in this process:

\subsection{Search}

First, we defined the field of study as the evaluation of website quality and established the period of our analysis as the years between 2000 and 2018. Search equations were then designed in both English and Spanish, based on the terms most commonly used in the literature (see Figure 1) in combination with Boolean operators.

\begin{tabular}{|c|} 
(website OR "web site" OR "web sites") \\
AND (quality) AND \\
(assessment OR assess OR assessing OR assurance OR evaluation OR evaluating OR evaluate OR analysis OR index OR heuristic OR standard OR \\
guideline)
\end{tabular}

Figure 1. Search equation used in databases and specialized engines

Figure 2 shows the document search and selection process that we carried out in January 2019. Our universe was defined by the most important multidisciplinary academic databases: namely Scopus and Web of Science (WoS) Core CoIlection. A comprehensive consultation was performed in all disciplines, applied to the title, abstract and keyword fields, the results of which were ordered by relevance. Given the high documentary noise detected, we opted to select the first two hundred most relevant documents in English from each database, plus the 41 studies detected with the equation in Spanish.

We also used the Google Scholar search engine, because of its greater coverage, vast international presence (Martín-Martín et al., 2018) and so as not to only include journal articles, but also books and other technical documents (Thelwall; Kousha, 2015) employed in the field of website design and development. The search yielded approximately 127,000 results, of which the first hundred were analysed, also ordered by relevance.

Additionally, we used a number of specialized databases, including LISTA (Library, Information Science \& Technology Abstracts) collection available on the EBSCOhost platform, IEEE Xplore and ACM Digital Library, as well as other bibliographic information resources, including Emerald Insight, Dialnet Plus, SciELO, Microsoft Academic, DOAJ, Mendeley, ResearchGate, Dimensions, Semantic Scholar, 1Findr, and Lens, which contributed a further 245 papers that met our inclusion criteria.

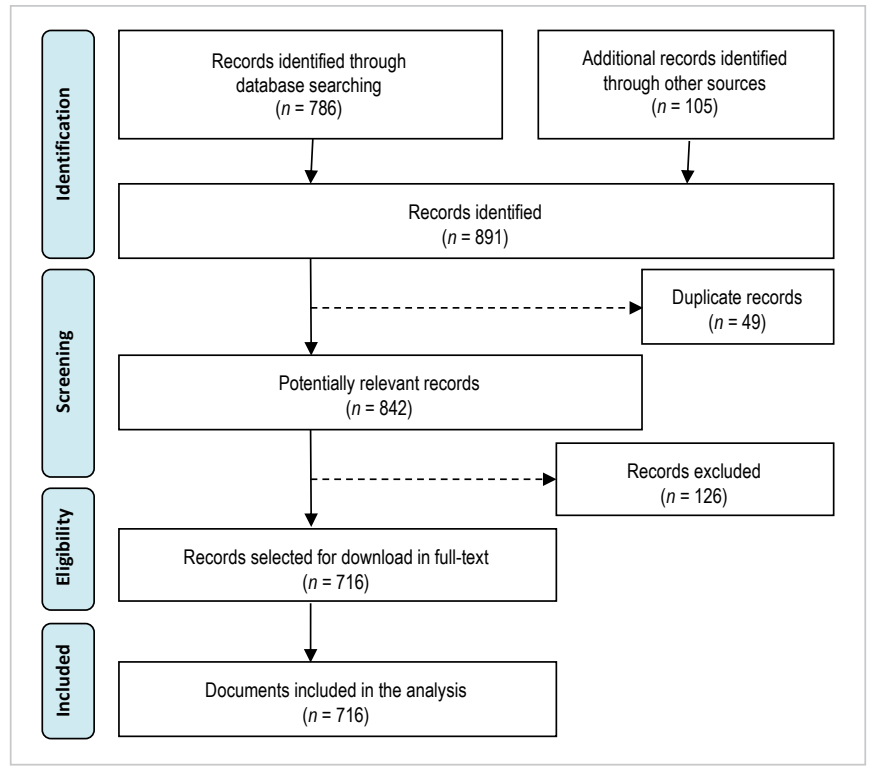

Figure 2. Text selection flowchart, an adaptation of the Prisma model (Moher et al., 2009)

The academic documents recovered with these sources were complemented with an additional 53 texts of a technical and/or professional nature, as well as with international standards and government and industry guidelines on website quality. To localize these texts, we implemented the review methods of mapping and systematic mapping.

Finally, we examined each of the bibliographic references in the previously identified studies undertaking state of the art or systematic reviews of website quality (see Table 1) and identified a further 52 new documents, giving us a total of 891 texts. However, we detected 49 duplicate articles, due primarily to the overlap between the WoS and Scopus databases, which we proceeded to eliminate. Thus, our searches allowed us to identify 842 documents.

\subsection{Appraisal}

After completing the search, all the texts recovered were reviewed manually, their titles and abstracts being examined in order to determine if they fulfilled the criteria detailed below: 


\section{Inclusion criteria:}

- Thematic relevance: Documents about website quality in general. Studies describing procedures and/or tools for the quality assessment of websites.

- Publication type: articles from scientific journals and communications published in conference proceedings as well as international standards, institutional guidelines, books with expert recommendations, style guides and technical reference documents for professionals.

- Language: English or Spanish.

- Publication date: during or after 2000.

\section{Exclusion criteria:}

- Studies of tools designed for a specific website, as well as case studies examining a single website.

- Web analytics studies or those based solely on visit statistics or on performance indicators, impact factors or conversion rates.

- Studies focused solely on the effects on the subject or user psychology, their behaviour or perception of their experience, and which do not analyse the website.

- Documents referring solely to applications (apps).

\subsection{Analysis}

After conducting the appraisal and filtering out some of the downloaded records, a document bank (Yin, 2015) or evidence base was constituted with 716 publications -589 in English (82.2\%) and 127 in Spanish (17.7\%)- which were managed using Mendeley reference software. Then, the metadata of the bibliographic information record for each item were cleaned and normalized using the OpenRefine software, and exported to an Excel table to facilitate their one-byone manual review and descriptive analysis.

Next, to each publication we added the number of citations received in Google Scholar, a search engine that provides this information not solely for journal articles, as is the case with other bibliometric measures. This indicator was collected in the last week of April 2019 for all texts.

As the older publications have enjoyed a longer period in which they could be cited, each publication was also associated with a normalized impact number, specifically: the average citation count (ACC) (Dey et al., 2018), which weights the number of citations with the number of years since its publication.

The affiliation of the authors of the studies was also registered, indicating their academic centre (research unit, department or faculty), university, and the nationality of that university. These details were recorded to enable us to analyse the countries and areas of knowledge with the greatest scientific-technical production in the field of study.

Using this information, a specific classification was drawn up by discipline based on a codebook (Lavrakas, 2008). After reviewing the categorizations proposed by UnesCo, OECD, WoS and Scopus, we opted to employ the nomenclature of the latter, using the following names of disciplines primarily related to web quality assessment in this database: computer science, business, health sciences, communication, library and information science, human-computer interaction ( $\mathrm{HCl})$, and others, including education and psychology.

However, we opted not to employ this taxonomy and treated all the categories at the same level, with the aim of making visible relevant sub-disciplines in this field of study, as is the case of $\mathrm{HCl}$.

\subsection{Synthesis}

All the information collected was synthesized on a spreadsheet in three separate areas:

a) Publication information:

- Bibliographic fields, that is, author(s), year, title, format, publisher, language, abstract and keywords, among others.

- Impact indicators: record of number of citations received in Google Scholar and average citation count.

b) Author(s) information:

- Country: defined by affiliation.

- Context or origin of the document: academic (scientific research), professional (technical document) and/or normative (government, international standard).

- Discipline: areas of knowledge, defined by faculty or department of affiliation.

c) Characteristics:

- Scope, level of specificity or range of application: general or sector-specific.

- Specific sector: education, government, health, tourism, commerce, or media.

- Quality attributes, methodologies and types of tool.

Finally, we used Excel to count the number of coincidences and NVivo software to analyse the frequency of terms. We present these results in the following section. 


\section{Results}

The most relevant results obtained from reviewing the 716 selected documents on website quality evaluation are presented below. They are organized in three sections: information about the publications, the authors and, finally, the text characteristics.

\subsection{Publications}

First, the evolution of scientific production over time and the distribution of the literature during the period covered by the study are presented (Figure 3). There is an upward trend in publication in this field, based on the number of papers published each year, especially in the first decade of the new millennium. In contrast, in the following decade, although the highest publication rates are reached, growth has become much more irregular.

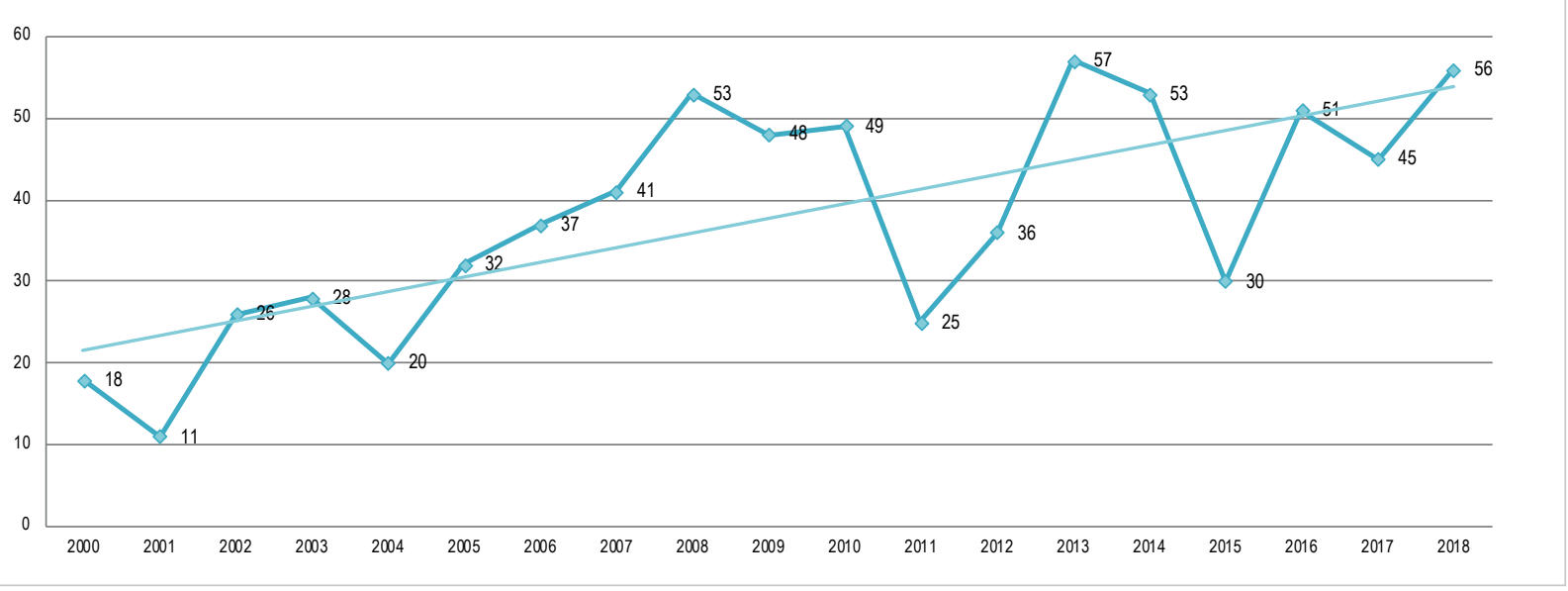

Figure 3. Annual production of publications on website quality

A study of the format of the publications under review (Table 2) shows that academic journal articles and conference proceedings account for more than $80 \%$ of the scientific production. The remaining $20 \%$ comprise books, technical reports and other types of so-called "grey literature", mostly used in professional settings. Although the journal articles receive a higher number of total citations in Google Scholar, books and web pages record a higher median number of citations.

Table 2. Format of the publications under review and total number of citations in Google Scholar (GS) and their median

\begin{tabular}{|c|c|c|c|c|}
\hline Format & Publications & $\%$ & GS citations & Median $n^{\circ}$ of GS citations \\
\hline Journal article & 455 & 63.5 & 30,594 & 17 \\
\hline Conference proceedings & 138 & 19.3 & 3,783 & 4 \\
\hline Book & 36 & 5.0 & 19,618 & 47 \\
\hline Thesis & 24 & 3.4 & 132 & 0 \\
\hline Technical report & 20 & 2.8 & 1,650 & 16 \\
\hline Book chapter & 18 & 2.5 & 467 & 5 \\
\hline Web & 18 & 2.5 & 1,005 & 30 \\
\hline Working document & 7 & 1.0 & 98 & 6 \\
\hline
\end{tabular}

Table 3. Journals with the highest number of publications on website quality $(\mathrm{N}=482)$

\begin{tabular}{|c|c|c|}
\hline Journal & Country & $\mathrm{N}^{\circ}$ of publications \\
\hline Revista española de documentación científica & Spain & 23 \\
\hline Online information review & United Kingdom & 10 \\
\hline Internet research & United Kingdom & 9 \\
\hline The electronic library & United States & 9 \\
\hline Profesional de la información & Spain & 7 \\
\hline Lecture notes in computer science & Germany & 7 \\
\hline Hipertext.net & Spain & 6 \\
\hline Journal of medical internet research & Canada & 6 \\
\hline International journal of electronic commerce & United States & 5 \\
\hline International journal of engineering and technology (UAE) & United Arab Emirates & 5 \\
\hline International journal of information management & United Kingdom & 5 \\
\hline Aslib proceedings & United Kingdom & 4 \\
\hline Government information quarterly & United Kingdom & 4 \\
\hline Information \& management & Netherlands & 4 \\
\hline
\end{tabular}


Note that in order to compare the number of citations received by the various publication formats, the median was calculated. We opted for this measure of centrality as opposed to the mean because of some highly extreme values. In the corpus of documents analysed some documents record no citations while others have received thousands.

We found a very wide variety of publications that publish studies related to website quality evaluation methods. Moreover, they belong to various scientific disciplines or areas of knowledge. Our study includes works from 298 different journal titles, 74 of which belong to the domain of healthcare and medical informatics. The journals that publish the most articles on this subject, and on the most regular basis, are those in the fields of library and information science, as verified by Table 3.

A similar degree of diversity is observed in the publishers that publish books and conference proceedings, with a predominance here of those specializing in engineering and the computer sciences, most notably IEEE and ACM Press, with 32 items. Emerald Group Publishing Limited, Springer International Publishing, Elsevier, North-Holland, and Pergamon also stand out in this regard.

In terms of the net number of citations recorded in Google Scholar, the analysis shows that the most cited publications correspond to the professional world and primarily to books, several of which can be considered seminal works in the field of website design and quality. In fact, the most cited works (Table 4) are headed by the main reference on usability (Nielsen, 2000), followed by the foundational texts in information architecture (Morville; Rosenfeld, 2006) and user experience (Garrett, 2011). The the most cited works includes nine books, eight journal articles, two conference proceedings and a technical report containing a standard from the World Wide Web Consortium.

Table 4. Website quality publications with most net citations in Google Scholar (GS)

\begin{tabular}{|c|c|c|c|c|}
\hline Author(s) & Year & Title & Format & GS citations \\
\hline Nielsen & 2000 & Designing web usability: The practice of simplicity & B & 6,109 \\
\hline Morville; Rosenfeld & 2006 & Information architecture for the World Wide Web & B & 3,083 \\
\hline Garrett & 2011 & $\begin{array}{l}\text { The elements of user experience: User-centered design for the web and } \\
\text { beyond }\end{array}$ & $\mathrm{B}$ & 2,070 \\
\hline Liu; Arnett & 2000 & $\begin{array}{l}\text { Exploring the factors associated with web site success in the context of } \\
\text { electronic commerce }\end{array}$ & A & 2,058 \\
\hline Palmer & 2002 & Web site usability, design, and performance metrics & A & 2,039 \\
\hline Tullis; Albert & 2013 & $\begin{array}{l}\text { Measuring the user experience: Collecting, analyzing, and presenting } \\
\text { usability metrics }\end{array}$ & $\mathrm{B}$ & 1,949 \\
\hline Aladwani; Palvia & 2002 & $\begin{array}{l}\text { Developing and validating an instrument for measuring user-perceived } \\
\text { web quality }\end{array}$ & $A$ & 1,471 \\
\hline Tidwell & 2006 & Designing interfaces: Patterns for effective interaction design & B & 1,458 \\
\hline Agarwal; Venkatesh & 2002 & $\begin{array}{l}\text { Assessing a firm's web presence: A heuristic evaluation procedure for } \\
\text { the measurement of usability }\end{array}$ & A & 1,078 \\
\hline Loiacono; Watson; Goodhue & 2002 & WebQual: A measure of website quality & $\mathrm{C}$ & 1,058 \\
\hline
\end{tabular}

In total, 96 publications receive more than 100 citations each and almost half the works included in the document bank receive 10 or fewer citations each. Indeed, 107 publications, corresponding in the main to works published in the last two years, do not record a single citation.

Table 5. Journal articles with the highest number of average citations (average citation count, ACC)

\begin{tabular}{|c|c|c|c|c|}
\hline Author(s) & Year & Title & GS & ACC \\
\hline Palmer & 2002 & Web site usability, design, and performance metrics & 2,039 & 120 \\
\hline Liu; Arnett & 2000 & $\begin{array}{l}\text { Exploring the factors associated with web site success in the context of electro- } \\
\text { nic commerce }\end{array}$ & 2,058 & 108 \\
\hline Aladwani; Palvia & 2002 & $\begin{array}{l}\text { Developing and validating an instrument for measuring user-perceived web } \\
\text { quality }\end{array}$ & 1,471 & 87 \\
\hline Law; Qi; Buhalis & 2010 & $\begin{array}{l}\text { Progress in tourism management: A review of website evaluation in tourism } \\
\text { research }\end{array}$ & 618 & 69 \\
\hline Agarwal; Venkatesh & 2002 & $\begin{array}{l}\text { Assessing a firm's web presence: A heuristic evaluation procedure for the mea- } \\
\text { surement of usability }\end{array}$ & 1,078 & 63 \\
\hline Loiacono; Watson; Goodhue & 2007 & WebQual: An instrument for consumer evaluation of web sites & 710 & 59 \\
\hline Ivory; Hearst & 2001 & The state of the art in automating usability evaluation of user interfaces & 1,009 & 56 \\
\hline Huizingh & 2000 & The content and design of web sites: An empirical study & 935 & 49 \\
\hline Park; Gretzel & 2007 & Success factors for destination marketing web sites: A qualitative meta-analysis & 469 & 39 \\
\hline Cao; Zhang; Seydel & 2005 & B2C e-commerce web site quality: An empirical examination & 527 & 38 \\
\hline
\end{tabular}


Table 6. Books with the highest number of average citations (average citation count, ACC)

\begin{tabular}{|l|c|l|c|c|}
\hline \multicolumn{1}{|c|}{ Author(s) } & Year & \multicolumn{1}{c|}{ Title } & ACC \\
\hline Tullis; Albert & 2013 & Measuring the user experience: Collecting, analyzing, and presenting usability metrics & 1,949 & 325 \\
\hline Nielsen & 2000 & Designing web usability: The practice of simplicity & 6,109 & 322 \\
\hline Garrett & 2011 & The elements of user experience: User-centered design for the web and beyond & 2,070 & 259 \\
\hline Morville; Rosenfeld & 2006 & Information architecture for the World Wide Web & 3,083 & 237 \\
\hline Sauro; Lewis & 2012 & Quantifying the user experience: Practical statistics for user research & 553 & 184 \\
\hline Tidwell & 2006 & Designing interfaces: Patterns for effective interaction design & 1,458 & 112 \\
\hline Nielsen; Loranger & 2006 & Prioritizing web usability & 1,047 & 81 \\
\hline Shneiderman et al. & 2016 & Designing the user interface: Strategies for effective human-computer interaction & 197 & 66 \\
\hline Krug & 2014 & Don't make me think, revisited: A common sense approach to web and mobile usability & 326 & 65 \\
\hline Morville & 2005 & Ambient findability: What we find changes who we become & 837 & 60 \\
\hline
\end{tabular}

As mentioned, given that the oldest publications have been around longer to receive citations, we employed an average citation count (ACC), which normalizes the number of citations received in relation to the years that have elapsed since a text's publication. Thus, Table 5 shows the ten articles with the highest ACC and Table 6 does the same for books, revealing some differences with the list ordered by net citations in Google Scholar (GS).

\subsection{Authors}

A study of the authorship of these works shows that 1,873 authors were involved in the set of publications, giving an arithmetic mean of 2.6 authors per document. However, most of the identified authors (90.9\%) put their name to just one study, which is consistent with the median (Med $=1$ ).

Table 7. Authors with most publications on website quality in the period analysed $(N=1,873)$

\begin{tabular}{|c|c|c|c|}
\hline Author & Affiliation & Country & Publications \\
\hline Codina, Lluís & Communication Department, Universitat Pompeu Fabra & Spain & 13 \\
\hline Pedraza-Jiménez, Rafael & Communication Department, Universitat Pompeu Fabra & Spain & 10 \\
\hline Büyüközkan, Gülçin & Department of Industrial Engineering, Galatasaray Üniversitesi & Turkey & 9 \\
\hline Hasan, Layla & Department of Computer Information Systems, Zarqa University & Jordan & 6 \\
\hline Sastry, Jammalamadaka K. R. & Department of Electronics and Computer Science and Engineering, KL University & India & 6 \\
\hline Thelwall, Mike & School of Computing and Information Technology, University of Wolverhampton & United Kingdom & 6 \\
\hline Aguillo, Isidro F. & Cybermetrics Laboratory, CSIC & Spain & 5 \\
\hline Bevan, Nigel & Professional Usability Services & United Kingdom & 5 \\
\hline Lentz, Leo & Utrecht Institute of Linguistics, Universiteit Utrecht & Netherlands & 5 \\
\hline Olsina, Luis & School of Engineering, Universidad Nacional de La Plata & Argentina & 5 \\
\hline Orduña-Malea, Enrique & Trademetrics Research Group, Universitat Politècnica de València & Spain & 5 \\
\hline
\end{tabular}

In turn, for the period analysed, only 11 authors were associated with five or more publications included in the document bank for this study on website quality (Table 7). The co-authorship relations of these authors are shown in Figure 4.

The three disciplines that work most in the field of website quality show similar percentages of publications: human-computer interaction and library and information science, both with $11.5 \%$, and communication with $8.9 \%$. Other disciplines such as education and psychology account for $4.5 \%$.

Similarly, a study of the universities to which the authors are affiliated allows us to identify where most studies in this field are published. Figure 6 shows that the United States (23\%) and Spain (19\%) clearly lead what is otherwise a diverse list of 75 countries and international organizations (including Unesco and the European Union) in this area of knowledge. They are followed by the United Kingdom, China, India and Turkey.

Europe predominates, with 39\% of the publications (308 of the 775 authors), and is followed by America (26\%), Asia (26\%), Africa (5\%) and Oceania (4\%).

Finally, based on the authors' affiliation, we can also determine the professional field of origin and the context in which the document was written. Figure 7 shows that 660 works, that is, the vast majority, are academic in origin, and appeared in a scientific publication. Of the remaining texts, 39 -primarily books, technical reports and working documentsbelong to the professional field, while 17 correspond to normative documents, international standards, and government guidelines. 


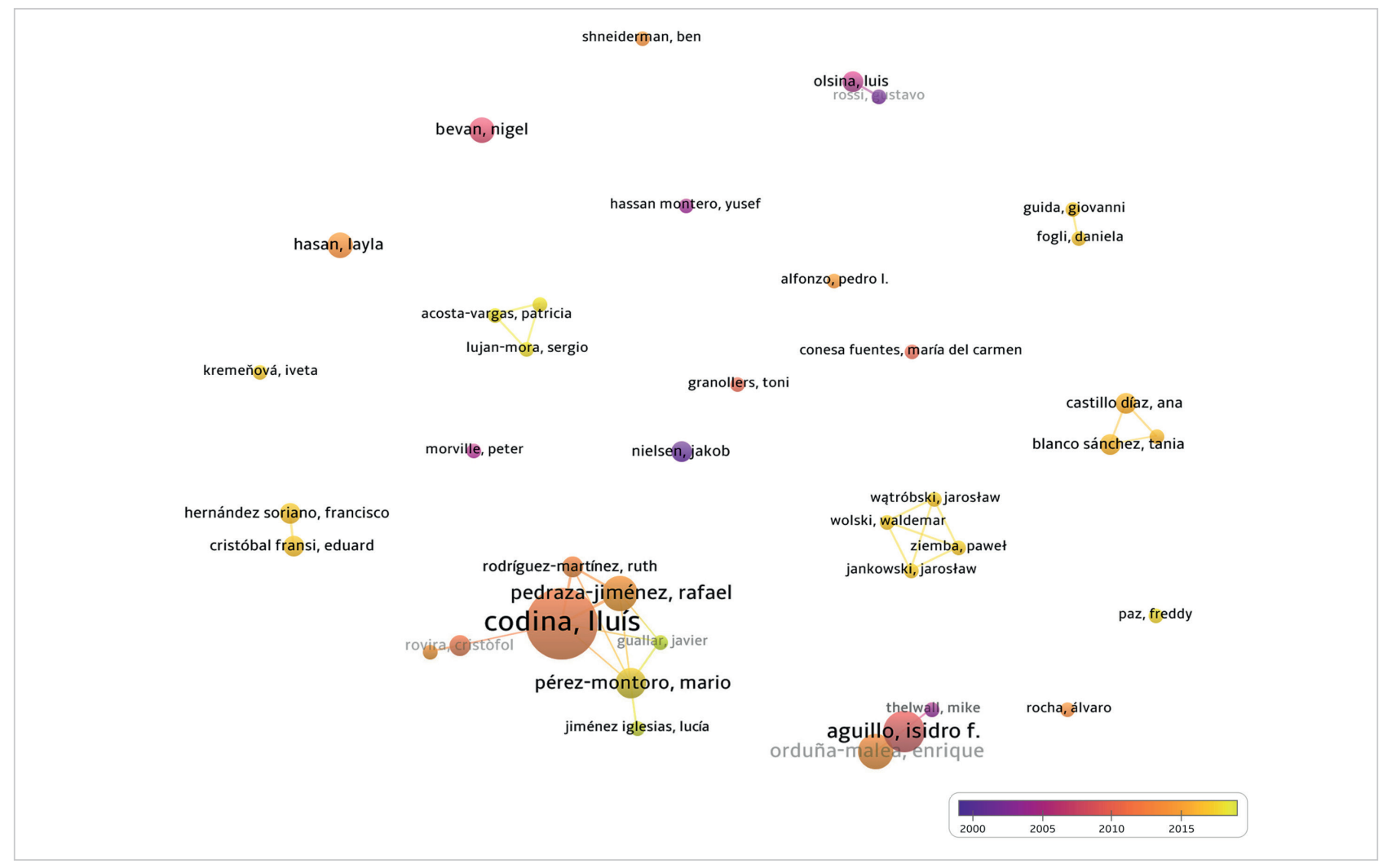

Figure 4. Authors with most works in terms of co-authorship and year of publication

\subsection{Characteristics}

Following an examination of all titles and abstracts, we were able to characterise the type of website for which the quality assessment method or tool developed in each publication was intended. Some tools are designed for general use, that is, they were designed to analyse any type of website, while others are specific, that is, designed for a specific sector. Of the publications, $32.7 \%$ concern themselves with the quality attributes common to all websites, while $67.3 \%$ focus on a website specific to a given sector (Table 8).

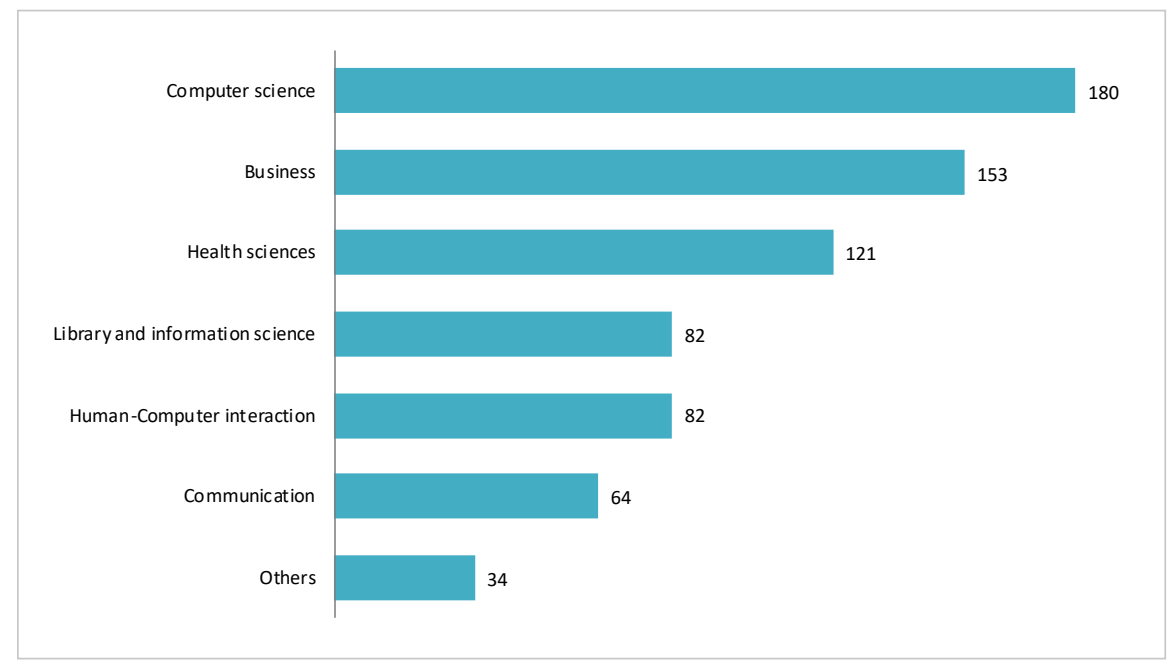

Figure 5. Discipline or origin of the works according to author affiliations $(N=716)$

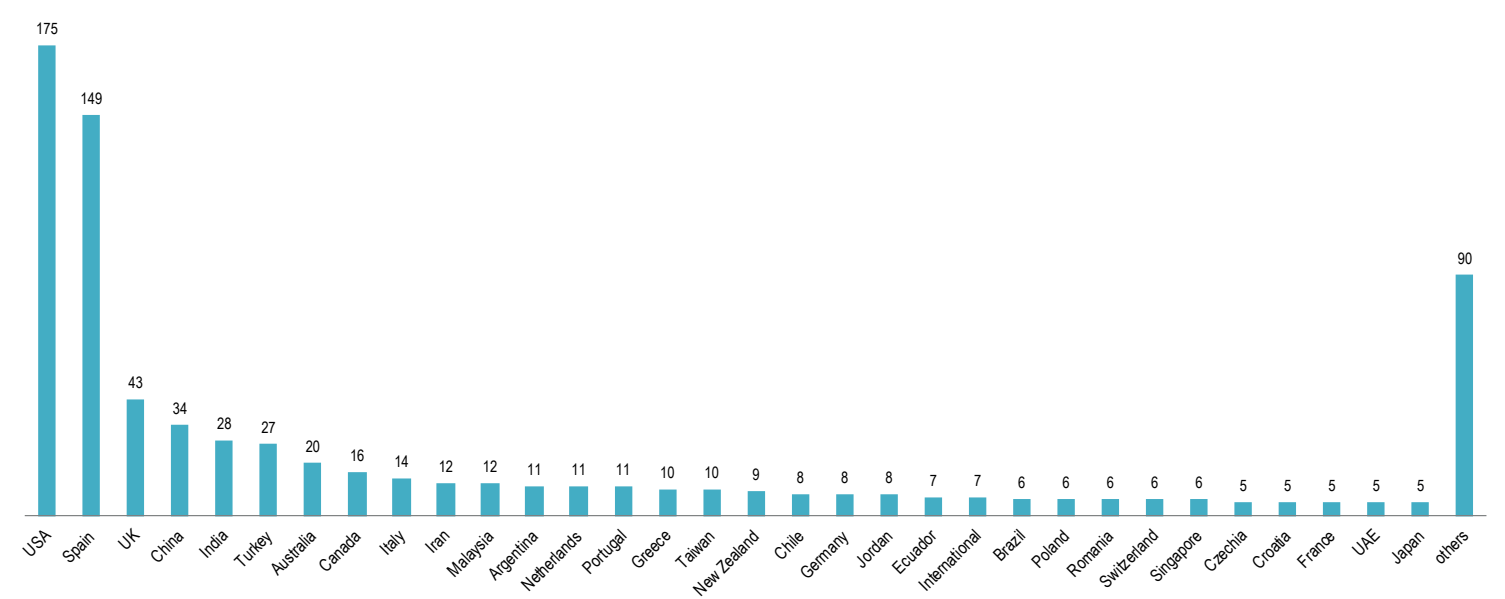

Figure 6. Countries with most publications, according to the author's country of origin ( $N=775)$ 
Table 8. Scope or level of specificity of the publication, citations in Google Scholar and median citation score

\begin{tabular}{|c|c|c|c|c|}
\hline Type of website & $\begin{array}{c}\text { No of } \\
\text { publications }\end{array}$ & $\%$ & $\begin{array}{c}\text { GS } \\
\text { citations }\end{array}$ & $\begin{array}{c}\text { GS median } \\
\text { score }\end{array}$ \\
\hline General & 234 & 32.7 & 38,865 & 18 \\
\hline Sector & 482 & 67.3 & 18,492 & 12 \\
\hline Education & 161 & 33.4 & 669 & 4 \\
\hline Health & 130 & 27.0 & 3,799 & 14 \\
\hline Commerce & 101 & 21.0 & 8,708 & 12 \\
\hline Government & 49 & 10.2 & 1,179 & 12 \\
\hline Tourism & 28 & 5.8 & 1,934 & 13 \\
\hline Media & 13 & 2.7 & 148 & 2 \\
\hline
\end{tabular}

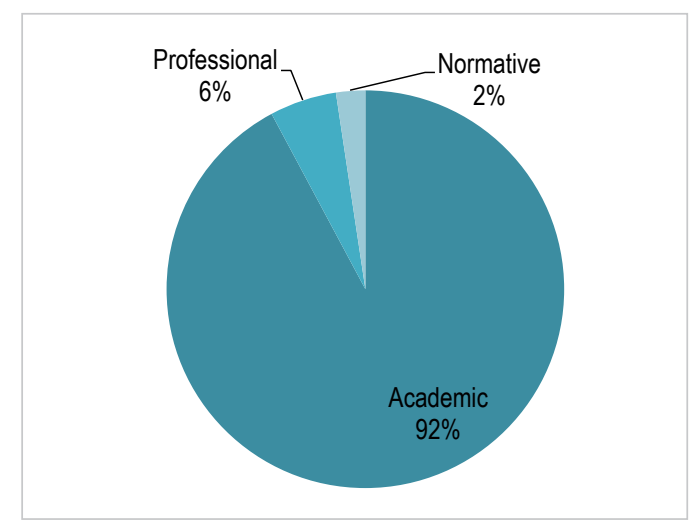

Figure 7. Context of origin of the publications according to author affiliations

However, the general publications receive the highest number of citations in Google Scholar and also present the highest median count. Among the sector studies, the most cited by far are those originating in the field of commerce, although those originating in the health sector have the highest median citation count. In addition, it is evident that while the scientific production on general website quality assessment instruments remained constant across the period, as of 2007 there was an increa-

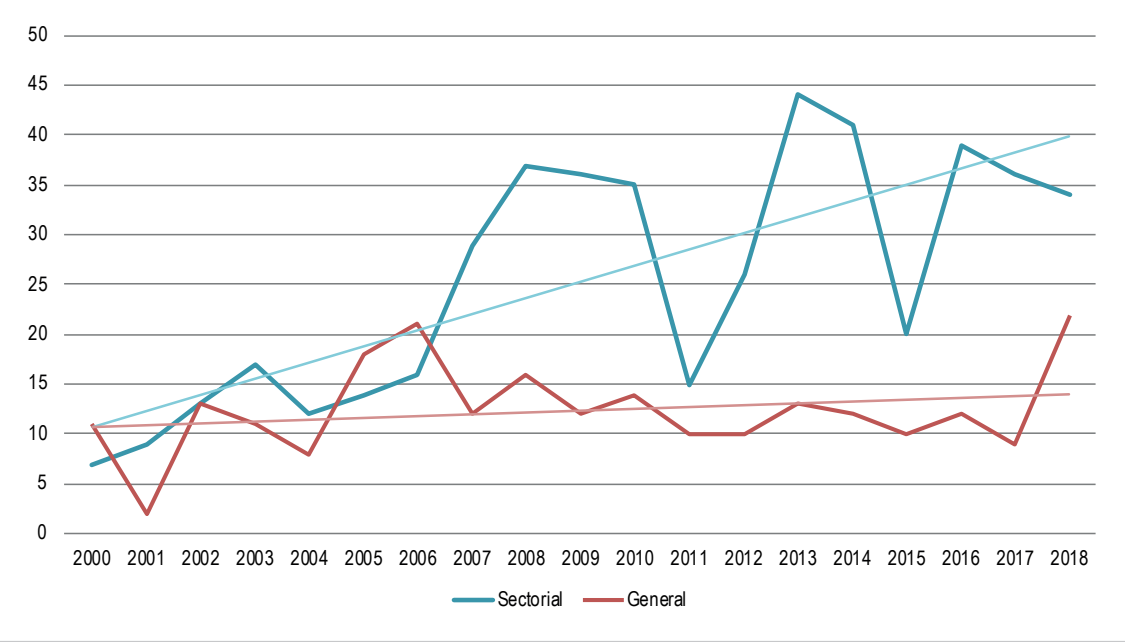

Figure 8. General and sector-specific publications by year se in the number of works by sector or those concerned with specific types of website (Figure 8). Among the latter, Table 9 records the three publications with the highest average citation count (ACC) in each of the sectors.

The education and culture sector, which accounts for $33.4 \%$ of the publications, includes studies of the websites of universities, libraries, museums, schools, e-learning platforms and online courses, while the health sector (hospitals and medical and psychological information site) accounts for $26.9 \%$ of publications, comprising in the main articles assessing the credibility of the content available on the internet about diseases and treatments.

A further $20.9 \%$ of specific publications concern themselves with commerce, essentially Internet businesses and e-commerce, and include the website quality assessment of department stores (retail), online auctions and online sales sites of such goods as books, wine and clothing. This group also includes studies of industrial and business processes, including recruitment, marketing and corporate reputation. The publications in this sector receive the most citations and are the studies that concentrate the most proposals based on website quality evaluation software and mathematical models for multi-criteria decision-making.

Studies of the quality of government websites account for $10.1 \%$ of the sector-specific production in this field. They include studies of the websites of governments, parliaments and municipalities, as well as the internet presence of the political authorities.

Although closely related to the commerce sector, given the level of specificity of its websites, the tourism sector is considered a separate category here. The sector accounts for $5.81 \%$ of publications which concern themselves with the websites of specific holiday destinations, travel agencies, hotel booking, and online plane ticket purchases.

Finally, $2.7 \%$ of publications are concerned with the media and, more specifically, with the online press and digital (or cyber) media.

To further our examination of the characteristics of their content, more than a hundred website quality attributes -as identified in the fifty studies with the highest average citation counts, representing almost $70 \%$ of all citations receivedwere also analysed by performing a frequency count and systematically categorising these attributes in a set of thirteen dimensions. 
Table 9. Sector-specific publications with the highest ACC

\begin{tabular}{|c|c|c|c|c|}
\hline Author(s) & Year & Title & GS & ACC \\
\hline \multicolumn{5}{|l|}{ Education sector } \\
\hline Aguillo; Ortega; Fernández & 2008 & $\begin{array}{l}\text { Webometric Ranking of World Universities: Introduction, methodology, and future } \\
\text { developments }\end{array}$ & 201 & 18 \\
\hline Gordon; Berhow & 2009 & $\begin{array}{l}\text { University websites and dialogic features for building relationships with potential } \\
\text { students }\end{array}$ & 130 & 13 \\
\hline Unesco & 2018 & Unesco's internet universality indicators: A framework for assessing internet development & 10 & 10 \\
\hline \multicolumn{5}{|l|}{ Health sector } \\
\hline Hu; Shyam-Sundar & 2010 & Effects of online health sources on credibility and behavioral intentions & 305 & 34 \\
\hline Bilsel; Büyüközkan; Ruan & 2006 & A fuzzy preference-ranking model for a quality evaluation of hospital web sites & 198 & 15 \\
\hline Beredjiklian et al. & 2000 & $\begin{array}{l}\text { Evaluating the source and content of orthopaedic information on the internet: The } \\
\text { case of carpal tunnel syndrome }\end{array}$ & 228 & 12 \\
\hline \multicolumn{5}{|l|}{ Commerce sector } \\
\hline Liu; Arnett & 2000 & $\begin{array}{l}\text { Exploring the factors associated with web site success in the context of electronic } \\
\text { commerce }\end{array}$ & 2,058 & 108 \\
\hline Loiacono; Watson; Goodhue & 2007 & WebQual: An instrument for consumer evaluation of web sites & 710 & 59 \\
\hline Cao; Zhang; Seydel & 2005 & B2C e-commerce web site quality: An empirical examination & 527 & 38 \\
\hline \multicolumn{5}{|l|}{ Government sector } \\
\hline Karkin; Janssen & 2014 & $\begin{array}{l}\text { Evaluating websites from a public value perspective: A review of Turkish local gover- } \\
\text { nment websites }\end{array}$ & 96 & 19 \\
\hline Huang; Benyoucef & 2014 & Usability and credibility of e-government websites & 85 & 17 \\
\hline Chua; Goh; Ang & 2012 & $\begin{array}{l}\text { Web } 2.0 \text { applications in government web sites: Prevalence, use and correlations with } \\
\text { perceived web site quality }\end{array}$ & 74 & 11 \\
\hline \multicolumn{5}{|l|}{ Tourism sector } \\
\hline Law; Qi; Buhalis & 2010 & Progress in tourism management: A review of website evaluation in tourism research & 618 & 69 \\
\hline Park; Gretzel & 2007 & Success factors for destination marketing web Sites: A qualitative meta-analysis & 469 & 39 \\
\hline Fernández-Cavia et al. & 2014 & $\begin{array}{l}\text { Web Quality Index (WQI) for official tourist destination websites. Proposal for an } \\
\text { assessment system }\end{array}$ & 100 & 20 \\
\hline \multicolumn{5}{|l|}{ Media sector } \\
\hline $\begin{array}{l}\text { Rodríguez-Martínez; } \\
\text { Codina; Pedraza-Jiménez }\end{array}$ & 2012 & $\begin{array}{l}\text { Indicadores para la evaluación de la calidad en cibermedios: Análisis de la interacción } \\
\text { y de la adopción de la Web } 2.0 \\
\text { [Indicators to evaluate the quality of online journalism web sites: an analysis of Web } \\
2.0 \text { interaction and adoption] }\end{array}$ & 89 & 13 \\
\hline Codina et al. & 2014 & $\begin{array}{l}\text { Sistema Articulado de Análisis de Cibermedios (SAAC): Una propuesta sobre el qué y } \\
\text { el cómo para estudiar medios de comunicación digitales } \\
\text { [Articulated System to Analyse Digital Media (ASADM): a proposal about what and } \\
\text { how to study online newspapers] }\end{array}$ & 21 & 4 \\
\hline Jowkar; Didegah & 2010 & Evaluating Iranian newspapers' web sites using correspondence analysis & 21 & 2 \\
\hline
\end{tabular}

As Table 10 shows, the attributes associated with website usability and content are the most frequently mentioned, followed by those of information architecture, user experience, graphic design, technology and security, interactivity, and performance and effectiveness; all of which are present in at least half the texts analysed.

As for the type of evaluation tool proposed in the most cited publications, we detect a predominance of expert analysis, in the form of heuristic tests, analytic systems or decision-making models. In this group we also include international standards and international guidelines. Finally, our analysis of the methodologies employed shows that checklists and scoring scales or indexes are the most frequent, above all in the health sector. Questionnaires and user tests are employed less frequently, but are a favourite approach in the commerce and tourism sectors.

\section{Discussion}

The results of the scientific production analysis of website quality evaluations presented here coincide in certain respects with the findings of Rekik et al. (2018). For example, the respective percentages of general and sector-specific publications are calculated in both studies at around $30 \%$ and $70 \%$, while both record a similar distribution across the sectors, with the exception of a considerable presence of texts examining social networks and media in the earlier study, a category that we have not specifically considered here. 
Our results also coincide with the outcomes reported in the review undertaken by Ugras et al. (2016) which, although focusing solely on usability studies, finds that education has been the sector attracting the greatest number of studies or the greatest research interest. In contrast with previous reviews, however, here we have found that tourism is a relevant sector for website quality assessment, so much so that we identify it as separate category in its in own right on the basis of the number of studies that focus specifically on it and the high citation scores achieved by some of these articles.

Table 10. Website quality attributes included in the documents with the highest average citation counts $(n=50)$

\begin{tabular}{|c|c|c|}
\hline Dimension & Presence & Related attributes \\
\hline Usability & $80 \%$ & $\begin{array}{l}\text { Accessibility, easy to use, customization, effectiveness, ease of comprehension, efficiency, reada- } \\
\text { bility, error prevention, user control, intuitive, learnability, context of use, flexibility }\end{array}$ \\
\hline Content & $80 \%$ & $\begin{array}{l}\text { Completeness and exhaustiveness, up-to-date, clarity, multilingualism, relevance, precision, } \\
\text { authority, conciseness, contact information, objectivity, linking of contents, written for the web, } \\
\text { attribution of authorship, writing and spelling, uniqueness and value added, visualisation of } \\
\text { information, truthfulness and rigour, persuasive discourse }\end{array}$ \\
\hline Information architecture & $76 \%$ & $\begin{array}{l}\text { Navigability, search, organization, labeling, mobile adaptability, localization and state, sitemap, } \\
\text { home page }\end{array}$ \\
\hline User experience & $66 \%$ & $\begin{array}{l}\text { Satisfaction, trust, credibility, utility and service, emotion, relevance, perceived value, expecta- } \\
\text { tions }\end{array}$ \\
\hline Graphic design & $66 \%$ & $\begin{array}{l}\text { Visual appeal, consistency and coherence, familiarity, adequate use of colour, balance and } \\
\text { contrast, corporate identity, simplicity and clarity, aesthetic integrity, creativity and innovation, } \\
\text { expressiveness of icons }\end{array}$ \\
\hline Technology and security & $60 \%$ & $\begin{array}{l}\text { Speed and response time, adherence to standards, link performance, availability and stability, } \\
\text { domain and URL, compatibility and interoperability }\end{array}$ \\
\hline Interactivity & $50 \%$ & Feedback, responsiveness, dialogue, gamification \\
\hline Performance and effectiveness & $50 \%$ & $\begin{array}{l}\text { Loyalty and trustworthiness, transactions, conversion, page views, reputation, return on invest- } \\
\text { ment, site size, traffic }\end{array}$ \\
\hline Legal aspects & $42 \%$ & $\begin{array}{l}\text { Privacy and confidentiality, data protection, transparency, declaration of sponsorship, copyright, } \\
\text { sensitive content }\end{array}$ \\
\hline Customer support & $38 \%$ & Help and documentation, customer service, frequently asked questions \\
\hline Advertising and marketing & $38 \%$ & Brand image, search engine optimization (SEO), special offers, sales orientation \\
\hline Multimedia & $34 \%$ & Images, graphics and photographs, video and audiovisual, animation, audio and sound \\
\hline Sociability and participation & $26 \%$ & Social networks, rating, community, opinions \\
\hline
\end{tabular}

As is usual in the scientific-technical field, journal articles are the most frequently chosen format (65\%) for disseminating the results of studies evaluating website quality. However, conference proceedings -which are widely published in the computer sciences- have also been found to be a frequent format for publishing findings, accounting for almost $20 \%$ of the documents studied in our review.

Here, the identification of more than a hundred studies of the quality of the content of websites on health problems and their medical treatment is also of some relevance. These studies are, moreover, highly cited and have a high degree of specificity, focusing both on the evaluation of sites on common illnesses and highly specific cures and treatments.

These documents are concerned with determining the veracity and reliability of medical information. For this reason, the majority draw on the HonCode protocol (Health On the Net Foundation, 2017), which certifies principles such as website authority, complementarity (that is, that the information supports rather than replaces), attribution, honesty and transparency in the treatment of content, with particular attention to aspects such as ethical rigour that are not always observed in other sectors.

To disseminate these studies, in addition to the journals specific to each specialty, there are a dozen specialized titles in the field of medical informatics that publish this type of website review, including: Journal of Medical Internet Research, Journal of Biomedical Informatics, and Health Communication.

Finally, a prominent aspect that this study has revealed is the presence of a large number of works on website quality based on multi-criteria decision making (MCDM) models, hybrid models, intuitive approaches and fuzzy methods as developed in the decision sciences.
There is a large number of works on web quality based on multi-criteria decision-making models and other methods typical of decision science 


\section{Conclusions}

The results of this paper indicate that, between 2000 and 2018, academic interest in the study of the evaluation of website quality and the identification of opportunities for improving website quality has increased. Over the last ten years, in particular, this is borne out by an increase in the number of publications.

Yet, as regards the actual concept of website quality, a sole definition has yet to be formulated in the studies reviewed here. While various approaches have been developed within the areas of software quality and quality-in-use, there is yet to be one that alludes specifically to all stakeholders in the website or which is based on a set of measurable attributes. For this reason, this study has proposed a new definition centred specifically on these particular aspects.

Returning to this study's first specific objective (SO 1) concerning the impact of the publications reviewed, we have been able to determine that the three most frequently cited works correspond to books in English for professionals working in the field. The list is headed by authors that are widely considered as being the "fathers" of the disciplines of usability, information architecture, and user experience. This result, however, contrasts with the preferred publication format of the documents studied, given that most are published as articles in scientific journals.

As for SO 2, concerning the primary affiliations of authors in this field, our study shows that among the 75 countries represented, universities in the United States and Spain have published most prolifically in this field. Moreover, Europe concentrates more than a third of the scientific production, followed by America and Asia.

Likewise, we have shown that website quality is a concept studied from a variety of different approaches and in distinct areas of knowledge, including communication, health, computer science and business, these last two areas contributing the greatest number of studies.

Finally, in relation to SO 3, concerning the orientation of these studies, we have shown that they increasingly tend to focus on specific sectors, including those of education, health and e-commerce, the three most predominant in the literature. In fact, we have been able to verify that an increasing number of texts are currently being published in which proposals are presented for the evaluation of specialist sites. At the same time, however, the publication of broader studies aimed at evaluating websites in general has remained stable -they are neither growing in number nor are they are the predominant form of scientific production- although they receive the highest number of citations.

As regards the methodologies employed in these studies, two main currents can be identified: expert analysis and user studies, with a predominance of the former, although we also identify studies focused on a range of different strategic aspects. The type of assessment tools and instruments employed in the documents analysed is varied, facilitating different levels of evaluation. They range from checklists to complex analytical systems, which can be applied manually, semi-automatically or in a fully automated mode.

Our study of the characteristics of the content shows that a high number of articles are concerned with the reliability of medical information on specialized websites and that a large number of studies are based on mathematical models for multi-criteria decision-making, designed primarily to analyse e-commerce sites.

Future research can usefully focus its attention on undertaking a systematic review of the assessment methodologies employed in the literature and the way in which the most frequently cited works apply them. Moreover, the results reported here call for a more in-depth study of the most frequently recurring parameters and indicators of the attributes of website quality, given the high degree of overlap detected between the articles studied. In this way, it should be possible to propose a taxonomy of the attributes of website quality that enjoy a high degree of consensus among academics and expert professionals in this field.

Finally, it would be interesting to undertake an intersectoral and interdisciplinary study to detect the extent to which the website quality instruments formulated for different types of website, emanating from very different fields of knowledge, complement each other. Indeed, website quality assessment is a multidisciplinary field of study subject to constant growth and one that continues to offer many opportunities for future research. Here, we have begun to highlight, however, the emergence of various trends, including the increase in sectoral systems and the introduction of semi-automated tools of analysis. Furthermore, perhaps owing to its multidisciplinary status, this field of knowledge has yet to be unified and has yet to consolidate the concepts and terms with which it operates, a task that sooner rather than later specialists will have to address. For the time being, we can conclude that this field is becoming increasingly specialized and diverse, like the web itself.
Web quality is a concept approached from various disciplines like communication, health, computer science or business 


\section{References}

Abadal, Ernest; Guallar, Javier (2018). "Scientific production on interaction in digital news media”. In: Pérez-Montoro, Mario (ed.). Interaction in digital news media: From principles to practice. Palgrave Macmillan, pp. 175-191. ISBN: 978 3319962528 https://doi.org/10.1007/978-3-319-96253-5_8

Abdallah, Salam; Jaleel, Bushra (2015). "Website appeal: development of an assessment tool and evaluation framework of e-marketing". Journal of theoretical and applied electronic commerce research, v. 10, n. 3, pp. 45-62. https://doi.org/10.4067/S0718-18762015000300005

Afonso, Ana-Paula; Reis-Lima, Jorge; Pérez-Cota, Manuel (2012). "A heuristic evaluation of usability of web interfaces". In: 7th Iberian Conference on Information Systems and Technologies (CISTI 2012), pp. 1-6. https://ieeexplore.ieee.org/document/6263192/

Agarwal, Ritu; Venkatesh, Viswanath (2002). “Assessing a firm's web presence: A heuristic evaluation procedure for the measurement of usability". Information systems research, v. 13, n. 2, pp. 168-186.

https://doi.org/10.1287/isre.13.2.168.84

Aguillo, Isidro F.; Ortega, José-Luís; Fernández, Mario (2008). "Webometric ranking of world universities: introduction, methodology, and future developments". Higher education in Europe, v. 33, n. 2-3, pp. 233-244.

https://doi.org/10.1080/03797720802254031

Aladwani, Adel M.; Palvia, Prashant C. (2002). "Developing and validating an instrument for measuring user-perceived web quality". Information \& management, v. 39, n. 6, pp. 467-476.

https://doi.org/10.1016/S0378-7206(01)00113-6

Allen, Mureen; Currie, Leanne M.; Bakken, Suzanne; Patel, Vimla L.; Cimino, James J. (2006). "Heuristic evaluation of paper-based web pages: a simplified inspection usability methodology". Journal of biomedical informatics, v. 39, n. 4 , pp. 412-423.

https://doi.org/10.1016/J.JBI.2005.10.004

Anusha, R. (2014). "A study on website quality models". International journal of scientific and research publications, v. 4, n. 12. http://www.ijsrp.org/research-paper-0115/ijsrp-p3768.pdf

Barnes, Stuart J.; Vidgen, Richard (2001). “An evaluation of cyber-bookshops: the webqual method”. International journal of electronic commerce, v. 6, n. 1, pp. 11-30.

https://doi.org/10.1080/10864415.2001.11044225

Beredjiklian, Pedro K.; Bozentka, David J.; Steinberg, David R.; Bernstein, Joseph (2000). "Evaluating the source and content of orthopaedic information on the internet: the case of carpal tunnel syndrome". The journal of bone and joint surgery, v. 82, n. 11, pp. 1540-1543.

https://doi.org/10.2106/00004623-200011000-00004

Bevan, Nigel (2005). "Guidelines and standards for web usability". In: Proceedings of the $11^{\text {th }}$ International Conference on Human-Computer Interaction. Las Vegas (HCl International), pp. 22-27.

https://citeseerx.ist.psu.edu/viewdoc/download?doi=10.1.1.111.3463\&rep=rep1\&type=pdf

Bevan, Nigel; Carter, James; Harker, Susan (2015). "ISO 9241-11 Revised: What have we learnt about usability since 1998?". In: Human-computer interaction: Design and evaluation, pp. 143-151.

https://link-springer-com.sare.upf.edu/chapter/10.1007/978-3-319-20901-2_13

Bilsel, R. Ufuk; Büyüközkan, Gülçin; Ruan, Da (2006). “A fuzzy preference-ranking model for a quality evaluation of hospital web sites". International journal of intelligent systems, v. 21, n. 11, pp. 1181-1197.

https://doi.org/10.1002/int.20177

Booth, Andrew; Sutton, Anthea; Papaioannou, Diana (2016). Systematic approaches to a successful literature review. London: SAGE Publications Ltd. ISBN: 9781473912465

Calero, Coral; Ruiz, Julián; Piattini, Mario (2005). "Classifying web metrics using the web quality model”. Online information review, v. 29, n. 3, pp. 227-248.

https://doi.org/10.1108/14684520510607560

Cao, Mei; Zhang, Qingyu; Seydel, John (2005). “B2C e-commerce web site quality: an empirical examination”. Industrial management \& data systems, v. 105, n. 5, pp. 645-661.

https://doi.org/10.1108/02635570510600000

Chiou, Wen-Chih; Lin, Chin-Chao; Perng, Chyuan (2010). "A strategic framework for website evaluation based on a review of the literature from 1995-2006". Information \& management, v. 47, n. 5-6, pp. 282-290.

https://doi.org/10.1016/J.IM.2010.06.002 
Chua, Alton Y. K.; Goh, Dion H; Ang, Rebecca P. (2012). "Web 2.0 applications in government web sites: prevalence, use and correlations with perceived web site quality". Online information review, v. 36, n. 2, pp. 175-195.

https://doi.org/10.1108/14684521211229020

Clifton, Brian (2012). Advanced web metrics with Google Analytics. Indianapolis, Indiana: John Wiley \& Sons, Inc. ISBN: 9781118168448

Codina, Lluís (2008). "Sistema general de análisis y evaluación de sitios web: parámetros e indicadores". Metodología de análisis y evaluación de recursos digitales en línea.

http://www.lluiscodina.com/wp-content/uploads/2014/04/indicadores_2008.pdf

Codina, Lluís (2018). Revisiones bibliográficas sistematizadas: procedimientos generales y framework para ciencias humanas y sociales.

https://repositori.upf.edu/handle/10230/34497

Codina, Lluís; Pedraza-Jiménez, Rafael (2016). “Características y componentes de un sistema de análisis de medios digitales: el SAAMD”. En: Pedraza-Jiménez, Rafael; Codina; Lluís; Guallar, Javier (coords.). Calidad en sitios web: Método de análisis general, e-commerce, imágenes, hemerotecas y turismo. Barcelona: Editorial UOC, pp. 15-40. ISBN: 978 84 90644874

Codina, Lluís; Pedraza-Jiménez, Rafael; Díaz-Noci, Javier; Rodríguez-Martínez, Ruth; Pérez-Montoro, Mario; Cavaller-Reyes, Víctor (2014). "Sistema Articulado de Análisis de Cibermedios (SAAC): Una propuesta sobre el qué y el cómo para estudiar medios de comunicación digitales". Hipertext.net, n. 12.

http://raco.cat/index.php/Hipertext/article/view/275560

Cutroni, Justin (2010). Google analytics. Sebastopol: O’Reilly Media, Inc. ISBN: 9780596158002

Dey, Arindam; Billinghurst, Mark; Lindeman, Robert W.; Swan, J. Edward (2018). "A systematic review of 10 years of augmented reality usability studies: 2005 to 2014". Frontiers in robotics and Al, v. 5.

https://doi.org/10.3389/frobt.2018.00037

Díaz, Ediber; Arenas, Juan-Jesús; Moquillaza, Arturo; Paz, Freddy (2019). “A systematic literature review about quantitative metrics to evaluate the usability of e-commerce web sites". In: Intelligent human systems integration $2019, \mathrm{pp}$. 332-338.

https://doi.org/10.1007/978-3-030-11051-2_51

Drăgulănescu, Nicolae-George (2002). “Website quality evaluations: Criteria and tools". The international information \& library review, v. 34, n. 3, pp. 247-254.

https://doi.org/10.1006/iilr.2002.0205

Fernández, Adrian; Insfran, Emilio; Abrahão, Silvia (2011). "Usability evaluation methods for the web: A systematic mapping study". Information and software technology, v. 53, n. 8, pp. 789-817.

https://doi.org/10.1016/J.INFSOF.2011.02.007

Fernández-Cavia, José; Rovira, Cristòfol; Díaz-Luque, Pablo; Cavaller, Víctor (2014). "Web Quality Index (WQI) for official tourist destination websites. Proposal for an assessment system". Tourism management perspectives, v. 9, pp. 5-13. https://doi.org/10.1016/j.tmp.2013.10.003

Fogli, Daniela; Guida, Giovanni (2015). "A practical approach to the assessment of quality in use of corporate web sites". Journal of systems and software, v. 99, pp. 52-65.

https://doi.org/https://doi.org/10.1016/j.jss.2014.09.006

Garrett, Jesse-James (2011). The elements of user experience: User-centered design for the web and beyond. Indianapolis: New Riders. ISBN: 9780321683687

González-Sánchez, José-Luis; Montero-Simarro, Francisco; Gutiérrez-Vela, Francisco-Luis (2012). “Evolución del concepto de usabilidad como indicador de calidad del software". El profesional de la información, v. 21, n. 5, pp. 529-536. https://doi.org/10.3145/epi.2012.sep.13

Gordon, Joye; Berhow, Susan (2009). "University websites and dialogic features for building relationships with potential students". Public relations review, v. 35, n. 2, pp. 150-152.

https://doi.org/10.1016/j.pubrev.2008.11.003

Gough, David; Oliver, Sandy; Thomas, James (2017). An introduction to systematic reviews. London: SAGE Publications Ltd. ISBN: 9781473929432

https://uk.sagepub.com/en-gb/eur/an-introduction-to-systematic-reviews/book245742\#description

Grant, Maria J.; Booth, Andrew (2009). "A typology of reviews: an analysis of 14 review types and associated methodologies". Health information \& libraries journal, v. 26, n. 2, pp. 91-108.

https://doi.org/10.1111/j.1471-1842.2009.00848.x 
Hasan, Layla; Abuelrub, Emad (2011). "Assessing the quality of web sites". Applied computing and informatics, v. 9, n. 1, pp. 11-29. https://doi.org/10.1016/j.aci.2009.03.001

Hassan-Montero, Yusef; Martín-Fernández, Francisco J. (2003). "Guía de evaluación heurística de sitios web". No solo usabilidad, n. 2, 30 marzo.

http://www.nosolousabilidad.com/articulos/heuristica.htm

Health On the Net Foundation (2017). "Principles: The HON code of conduct for medical and health web sites". HONcode, p. 1.

https://www.hon.ch/cgi-bin/HONcode/principles.pl

Hernández, Blanca; Jiménez, Julio; Martín, María-José (2009). “Key website factors in e-business strategy”. International journal of information management, v. 29, n. 5, pp. 362-371.

https://doi.org/10.1016/j.ijinfomgt.2008.12.006

Hu, Yifeng; Shyam-Sundar, S. (2010). "Effects of online health sources on credibility and behavioral intentions". Communication research, v. 37, n. 1, pp. 105-132.

https://doi.org/10.1177/0093650209351512

Huang, Zhao; Benyoucef, Morad (2014). "Usability and credibility of e-government websites". Government information quarterly, v. 31, n. 4, pp. 584-595.

https://doi.org/10.1016/j.giq.2014.07.002

Huizingh, Eelko K. R. E. (2000). "The content and design of web sites: an empirical study". Information \& management, v. 37, n. 3, pp. 123-134.

https://doi.org/10.1016/S0378-7206(99)00044-0

Internet Live Stats (2020). Internet usage \& social media statistics.

http://www.internetlivestats.com

ISO (2008). ISO 9241-151:2008. Ergonomics of human-system interaction. Part 151: Guidance on World Wide Web user interfaces.

https://www.iso.org/standard/37031.html

ISO (2015). ISO 9000:2015. Quality management systems - Fundamentals and vocabulary.

https://www.iso.org/obp/ui/\#iso:std:iso:9000:ed-4:v1:es

Ivory, Melody Y.; Hearst, Marti A. (2001). "The state of the art in automating usability evaluation of user interfaces". ACM computing surveys, v. 33, n. 4, pp. 470-516.

https://doi.org/10.1145/503112.503114

Jayanthi, B.; Krishnakumari, P. (2016). "An intelligent method to assess webpage quality using extreme learning machine". International journal of computer science and network security, v. 16, n. 9, pp. 81-85.

http://paper.ijcsns.org/07_book/201609/20160913.pdf

Jiménez, Cristhy; Rusu, Cristian; Roncagliolo, Silvana; Inostroza, Rodolfo; Rusu, Virginica (2012). "Evaluating a methodology to establish usability heuristics". In: $201231^{\text {st }}$ International Conference of the Chilean Computer Science Society. IEEE, pp. 51-59.

https://doi.org/10.1109/SCCC.2012.14

Jiménez-Iglesias, Lucía; Pérez-Montoro, Mario; Sánchez-Gómez, Lydia (2017). “Diseño de información digital: revisión y clasificación de indicadores heurísticos para contenidos web”. El profesional de la información, v. 26, n. 6, pp. 1029-1046. https://doi.org/10.3145/epi.2017.nov.03

Jowkar, Abdolrasoul; Didegah, Fereshteh (2010). “Evaluating Iranian newspapers' web sites using correspondence analysis". Library hi tech, v. 28, n. 1, pp. 119-130.

https://doi.org/10.1108/07378831011026733

Karkin, Naci; Janssen, Marijn (2014). "Evaluating websites from a public value perspective: A review of Turkish local government websites". International journal of information management, v. 34, n. 3, pp. 351-363. https://doi.org/10.1016/j.ijinfomgt.2013.11.004

Kaur, Satinder; Gupta, S. K. (2014). "Key aspects to evaluate the performance of a commercial website". In: IJCA Proceedings on International Conference on Advances in Computer Engineering and Applications. Icacea, n. 1, pp. 7-11. https://www.ijcaonline.org/proceedings/icacea/number1/15608-1422

Kaushik, Avinash (2010). Web analytics 2.0: The art of online accountability \& science of customer centricity. Wiley Publishing, Inc. ISBN: 9780470529393 
Kitchenham, Barbara; Charters, Stuart (2007). Guidelines for performing systematic literature reviews in software engineering.

http://citeseerx.ist.psu.edu/viewdoc/summary?doi=10.1.1.117.471

Krug, Steve (2014). Don't make me think, revisited: A common sense approach to web and mobile usability. Berkeley, California: Pearson Education. ISBN: 9780321965516

http://sensible.com/dmmt.html

Lavrakas, Paul J. (2008). Encyclopedia of survey research methods. Thousand Oaks, CA: Sage Publications, Inc. ISBN: 978 1412918084

https://doi.org/10.4135/9781412963947

Law, Rob; Qi, Shanshan; Buhalis, Dimitrios (2010). “Progress in tourism management: A review of website evaluation in tourism research". Tourism management, v. 31, n. 3, pp. 297-313.

https://doi.org/10.1016/j.tourman.2009.11.007

Leavitt, Michael O.; Shneiderman, Ben (2006). Research-based web design \& usability guidelines. Washington, DC. ISBN: 0160762707

https://www.usability.gov/sites/default/files/documents/guidelines_book.pdf

Liu, Chang; Arnett, Kirk P. (2000). "Exploring the factors associated with web site success in the context of electronic commerce". Information \& management, v. 38, n. 1, pp. 23-33.

https://doi.org/10.1016/S0378-7206(00)00049-5

Loiacono, Eleanor T.; Watson, Richard T.; Goodhue, Dale L. (2002). "WebQual: A measure of website quality". In: American Marketing Association: Winter Marketing Educators' Conference.

http://citeseerx.ist.psu.edu/viewdoc/download?doi=10.1.1.86.4410\&rep=rep1\&type=pdf

https://www.researchgate.net/publication/313001568_WEBQUAL_A_measure_of_website_quality_2002_Marketing_ Educators

Loiacono, Eleanor T.; Watson, Richard T.; Goodhue, Dale L. (2007). "WebQual: an instrument for consumer evaluation of web sites". International journal of electronic commerce, v. 11, n. 3, pp. 51-87.

https://doi.org/10.2753/JEC1086-4415110302

Lopezosa, Carlos (2019). SEO, periodismo y comunicación: conceptos, herramientas y procesos para optimizar la visibilidad web de los medios digitales. Tesis doctoral, Universitat Pompeu Fabra.

http://hdl.handle.net/10803/668121

Maia, Camila-Loiola-Brito; Furtado, Elizabeth-Sucupira (2016). "A systematic review about user experience evaluation". In: Marcus, Aaron (ed.). Design, user experience, and usability: Design thinking and methods, pp. 445-455. ISBN: 978 3 319404080 https://doi.org/10.1007/978-3-319-40409-7_42

Mariage, Céline; Vanderdonckt, Jean; Pribeanu, Costin (2006). "State of the art of web usability guidelines". In: Vu, KimPhuong L.; Proctor, Robert W. (eds.). Handbook of human factors in web design. Boca Raton: CRC Press Inc., pp. 688-700. ISBN: 9781439825945

Martín-Martín, Alberto; Orduña-Malea, Enrique; Thelwall, Mike; Delgado-López-Cózar, Emilio (2018). “Google Scholar, Web of Science, and Scopus: a systematic comparison of citations in 252 subject categories". Journal of informetrics, v. 12 , n. 4 , pp. $1160-1177$.

https://doi.org/10.1016/j.joi.2018.09.002

Matera, Maristella; Rizzo, Francesca; Carughi, Giovanni-Toffetti (2006). "Web usability: Principles and evaluation methods". In: Mendes, Emilia; Mosley, Nile (eds.). Web engineering. Berlin Heeidelberg: Springer-Verlag, pp. 143-180. ISBN: 9783540281962

https://doi.org/10.1007/3-540-28218-1_5

Moher, David; Liberati, Alessandro; Tetzlaff, Jennifer; Altman, Douglas G.; The Prisma Group (2009). “Preferred reporting items for systematic reviews and meta-analyses: The Prisma statement". PLoS medicine, v. 6, n. 7, p. e1000097. https://doi.org/10.1371/journal.pmed.1000097

Morville, Peter (2005). Ambient findability. Sebastopol, California: O’Reilly Media. ISBN: 0596007655 https://intertwingled.org/ambient-findability

Morville, Peter; Rosenfeld, Louis (2006). Information architecture for the World Wide Web. Sebastopol (California): O'Reilly. ISBN: 9780596527341

Nielsen, Jakob (2000). Designing web usability. Indianapolis, Indiana: New Riders. ISBN: 156205810X 
Nielsen, Jakob (2005). "10 usability heuristics for user interface design". Nielsen Norman Group, 24 April. https://www.nngroup.com/articles/ten-usability-heuristics

Nielsen, Jakob; Loranger, Hoa (2006). Prioritizing web usability. Berkeley, California: New Riders. ISBN: 9780321350312 https://www.nngroup.com/books/prioritizing-web-usability

Norman, Donald A. (2002). The design of everyday things. New York: Basic Books. ISBN: 0465067107

Olsina, Luis; Covella, Guillermo; Rossi, Gustavo (2006). "Web quality”. In: Mendes, Emilia; Mosley, Nile (eds.). Web engineering. Berlin, Heidelberg: Springer-Verlag, pp. 109-142. ISBN: 9783540281962

https://doi.org/10.1007/3-540-28218-1_4

Orduña-Malea, Enrique; Aguillo, Isidro F. (2014). Cibermetría: midiendo el espacio red. Barcelona: Editorial UOC. ISBN: 9788490642337

Palmer, Jonathan W. (2002). "Web site usability, design, and performance metrics". Information systems research, v. 13, n. 2, pp. 151-167.

https://doi.org/10.1287/isre.13.2.151.88

Park, Young A.; Gretzel, Ulrike (2007). "Success factors for destination marketing web sites: a qualitative meta-analysis". Journal of travel research, v. 46, n. 1, pp. 46-63.

https://doi.org/10.1177/0047287507302381

Pedraza-Jiménez, Rafael; Codina, Lluís; Guallar, Javier (2016). Calidad en sitios web: Método de análisis general, e-commerce, imágenes, hemerotecas y turismo, Barcelona: Editorial UOC. ISBN: 9788490644874

Pérez-Montoro, Mario; Codina, Lluís (2017). Navigation design and SEO for content-intensive websites: a guide for an efficient digital communication. Cambridge, MA: Chandos Publishing - Elsevier. ISBN: 9780081006771

http://www.sciencedirect.com/science/book/9780081006764

Pribeanu, Costin (2009). "A usability assistant for the heuristic evaluation of interactive systems". Studies in informatics and control, v. 18, n. 4, pp. 355-362.

https://sic.ici.ro/a-usability-assistant-for-the-heuristic-evaluation-of-interactive-systems

Quiñones, Daniela; Rusu, Cristian (2017). "How to develop usability heuristics: a systematic literature review". Computer standards \& interfaces, v. 53, pp. 89-122.

https://doi.org/10.1016/J.CSI.2017.03.009

Ramler, Rudolf; Weippl, Edgar; Winterer, Mario; Schwinger, Wieland; Altmann, Josef (2002). "A quality-driven approach to web testing". In: Proceedings of ICWE'02 Conference, pp. 81-95.

https://citeseerx.ist.psu.edu/viewdoc/download?doi=10.1.1.216.6925\&rep=rep1\&type=pdf

Rekik, Rim; Kallel, Ilhem; Alimi, Adel M. (2015). "Quality evaluation of web sites: a comparative study of some multiple criteria decision making methods". In: $15^{\text {th }}$ International Conference on Intelligent Systems Design and Applications (ISDA), pp. 585-590. ISBN: 9781467387095

https://ieeexplore.ieee.org/abstract/document/7489183

Rekik, Rim; Kallel, Ilhem; Casillas, Jorge; Alimi, Adel M. (2018). “Assessing web sites quality: a systematic literature review by text and association rules mining". International journal of information management, v. 38, n. 1, pp. $201-216$. https://doi.org/10.1016/J.IJINFOMGT.2017.06.007

Rocha, Álvaro (2012). "Framework for a global quality evaluation of a website". Online information review, v. 36, n. 3, pp. 374-382.

https://doi.org/10.1108/14684521211241404

Rodríguez-Martínez, Ruth; Codina, Lluís; Pedraza-Jiménez, Rafael (2012). “Indicadores para la evaluación de la calidad en cibermedios: análisis de la interacción y de la adopción de la web 2.0". Revista española de documentación científica, v. 35, n. 1, pp. 61-93.

https://doi.org/10.3989/redc.2012.1.858

Rubin, Jeffrey; Chisnell, Dana (2008). Handbook of usability testing: How to plan, design, and conduct effective tests. Indianapolis, Ind.: Wiley. ISBN: 9780470185483

Sanabre-Vives, Carles; Pedraza-Jiménez, Rafael; Vinyals-Mirabent, Sara (2020). “Double-entry analysis system for comprehensive quality evaluation of websites: case study in the tourism sector". Profesional de la información, v. 29, n. 4, e290432.

https://doi.org/10.3145/epi.2020.jul.32 
Sanabre-Vives, Carles; Pedraza-Jiménez, Rafael; Codina, Lluís (2018). "Website canvas model: propuesta de un modelo visual para la ideación estratégica de sitios web". Revista española de documentación científica, v. 41, n. 4, p. 221. https://doi.org/10.3989/redc.2018.4.1542

Sauro, Jeff (2010). A practical guide to measuring usability: Quantifying the usability of websites and software. CreateSpace. ISBN: 9781453806562

Sauro, Jeff; Lewis, James R. (2012). Quantifying the user experience: practical statistics for user research. Waltham, MA: Elsevier / Morgan Kaufmann. ISBN: 9780123849687

Semerádová, Tereza; Weinlich, Petr (2020). "Looking for the definition of website quality". In: Semerádová, Tereza; Weinlich, Petr. Website quality and shopping behavior: Quantitative and qualitative evidence. Springer Nature, pp. 5-27. ISBN: 9783030444396 https://doi.org/10.1007/978-3-030-44440-2_2

Shneiderman, Ben (2000). "Universal usability". Communications of the ACM, v. 43, n. 5, pp. 84-91. https://doi.org/10.1145/332833.332843

Shneiderman, Ben (2016). "The eight golden rules of interface design". Department of Computer Science, University of Maryland.

https://www.cs.umd.edu/users/ben/goldenrules.html

Tapia-León, Mariela (2015). "Factores de calidad en sitios web de destinos turísticos: estado de la cuestión”. Hipertext. net, n. 13. https://doi.org/10.2436/20.8050.01.23

Thelwall, Mike (2002). "Conceptualizing documentation on the web: an evaluation of different heuristic-based models for counting links between university web sites". Journal of the American Society for Information Science and Technology, v. 53 , n. 12 , pp. $995-1005$. http://doi.wiley.com/10.1002/asi.10135

Thelwall, Mike; Kousha, Kayvan (2015). "Web indicators for research evaluation. Part 1: Citations and links to academic articles from the web". El profesional de la información, v. 24, n. 5, pp. 587-606.

https://doi.org/10.3145/epi.2015.sep.08

Tidwell, Jenifer (2006). Designing interfaces: Patterns for effective interaction design. Cambridge, MA: O’Reilly. ISBN: 0596008031

Tognazzini, Bruce (2014). "First principles of interaction design (revised and expanded)". Ask TOG: Interaction design solutions for the real world.

https://asktog.com/atc/principles-of-interaction-design

Tonkin, Sebastian; Whitmore, Caleb; Cutroni, Justin (2010). Performance marketing with Google Analytics: Strategies and techniques for maximizing online ROI. ISBN: 9780470578315

Tullis, Thomas; Albert, William (2013). Measuring the user experience: Collecting, analyzing, and presenting usability metrics. Morgan Kaufmann. ISBN: 9780123735584

Ugras, Tuba; Gülseçen, Sevinç; Çubukçu, Ceren; Erdoğmuş, İpek ili; Gashi, Vala; Bedir, Merve (2016). "Research trends in web site usability: A systematic review". In: Marcus, Aaron (ed.). Design, user experience, and usability: Design thinking and methods. Springer, pp. 517-528. ISBN: 9783319404097

https://doi.org/10.1007/978-3-319-40409-7_49

Unesco (2018). Unesco's internet universality indicators: A framework for assessing internet development. Paris: United Nations Educational, Scientific and Cultural Organization. ISBN: 9789231003141

https://unesdoc.unesco.org/ark:/48223/pf0000367617

Wątróbski, Jarosław; Ziemba, Paweł; Jankowski, Jarosław; Wolski, Waldemar (2016). "Pequal. E-commerce websites quality evaluation methodology". Annals of computer science and information systems, v. 8, pp. 1317-1327.

https://doi.org/10.15439/2016F469

Webster, Jane; Watson, Richard T. (2002). "Analyzing the past to prepare for the future: Writing a literature review". MIS quarterly, v. 26, n. 2, pp. xiii-xxiii.

http://www.jstor.org/stable/4132319

Yin, Robert K. (2015). Qualitative research from start to finish. London: The Guilford Press. ISBN: 9781462517978 https://www.guilford.com/books/Qualitative-Research-from-Start-to-Finish/Robert-Yin/9781462517978 